\title{
ARTICLES
}

\section{ASSESSMENTS OF THE GROWTH RATE OF SIBERIAN LARCH (LARIX SIBIRICA LEDEB.) AND ITS DISTRIBUTION IN THE MONGOLIAN ALTAI MOUNTAIN RANGE}

\author{
Battulga P. ${ }^{*}$, Tsogtbaatar.$^{1}{ }^{1}$ and Gerelbaatar $S .^{2}$ \\ ${ }^{I}$ Forest Resource and Protection Division, Institute of Geography-Geoecology, \\ Mongolian Academy of Sciences, Ulaanbaatar, Mongolia \\ ${ }^{2}$ School of Applied Science and Engineering, National University of Mongolia, \\ Ulaanbaatar, Mongolia
}

ARTICLE INFO: Received: 2 Mar, 2018; Accepted: 25 Dec, 2018

\begin{abstract}
The Mongolian Altai mountain range stretches from east to west for more than 800 kilometers, and its forest cover is considered the southwestern boundary of the distribution of Mongolian forests and is characterized by a unique combination of high-mountain and desert ecosystems. Siberian larch (Larix sibirica Ledeb.) is one of the main forest-forming tree species in the Mongolian Altai and covers 112.0 thousand ha of area and is distributed at an altitude of 2300 to $2700 \mathrm{~m}$ a.s.l. In this study, we attempted a comparative study of tree growth rates in larch forests, which are associated with four different altitudinal zones in the Mongolian Altai, aimed at determinining the lower and upper limits of forest distribution in this region. We used the natural quantitative indicators in this study.

We carried out the diameter growth rate analyses on 15 model tree samples taken from the Mongolian Altai and 4 samples from Central Khangai regions. All the trees were divided into fast-growing and slow-growing. The results of the assessments showed that 60 percent of the studied forests belonged to slow-growing forests. Slowest growth rate was observed in the forests of Khan Taishir and Khar Azarga mountains, which are the southernmost tip of conifer forest distribution in Mongolia.

For the first time in Mongolia we observed that the upper limit of larch forests reached up to $2700 \mathrm{~m}$ a.s.l. Such slow rate of tree growth in larch forests is the result of the existing harsh continental climate, aridity, and high altitudinal distribution in the Mongolian Altai. Our findings can become the scientific basis for the development of a sustainable forest management plan in the forests of the Mongol Altai, taking into account the different growth rate between stands..
\end{abstract}

Keywords: Larch; forest altitudinal zone; growth rate; natural quantitative index; Altai, Mongolia;

\section{INTRODUCTION}

The high Altai mountains are distributed along the western and south-western border of the country (longitude E $94^{\circ}-98^{\circ}$ and latitude
$\mathrm{N} 45^{\circ}-47^{\circ}$ ), and the forests of this region are considered as the western limit of the Mongolian temperate forests (Fig. 1). Forest 
cover of the Mongolian Altai is 112.0 thousand hectares, which occupies only $1 \%$ of the total forested area of the country. According to forest vegetation zoning, the study region belongs to the zone of the Central Asian Forest Vegetation Zone [1]. The climate in the Mongolian Altai is characterized by extreme continental weather, because of the surrounding desert and dry steppe ecosystems. The main part of the forests is primarily distributed in Khasagt Khairkhan,

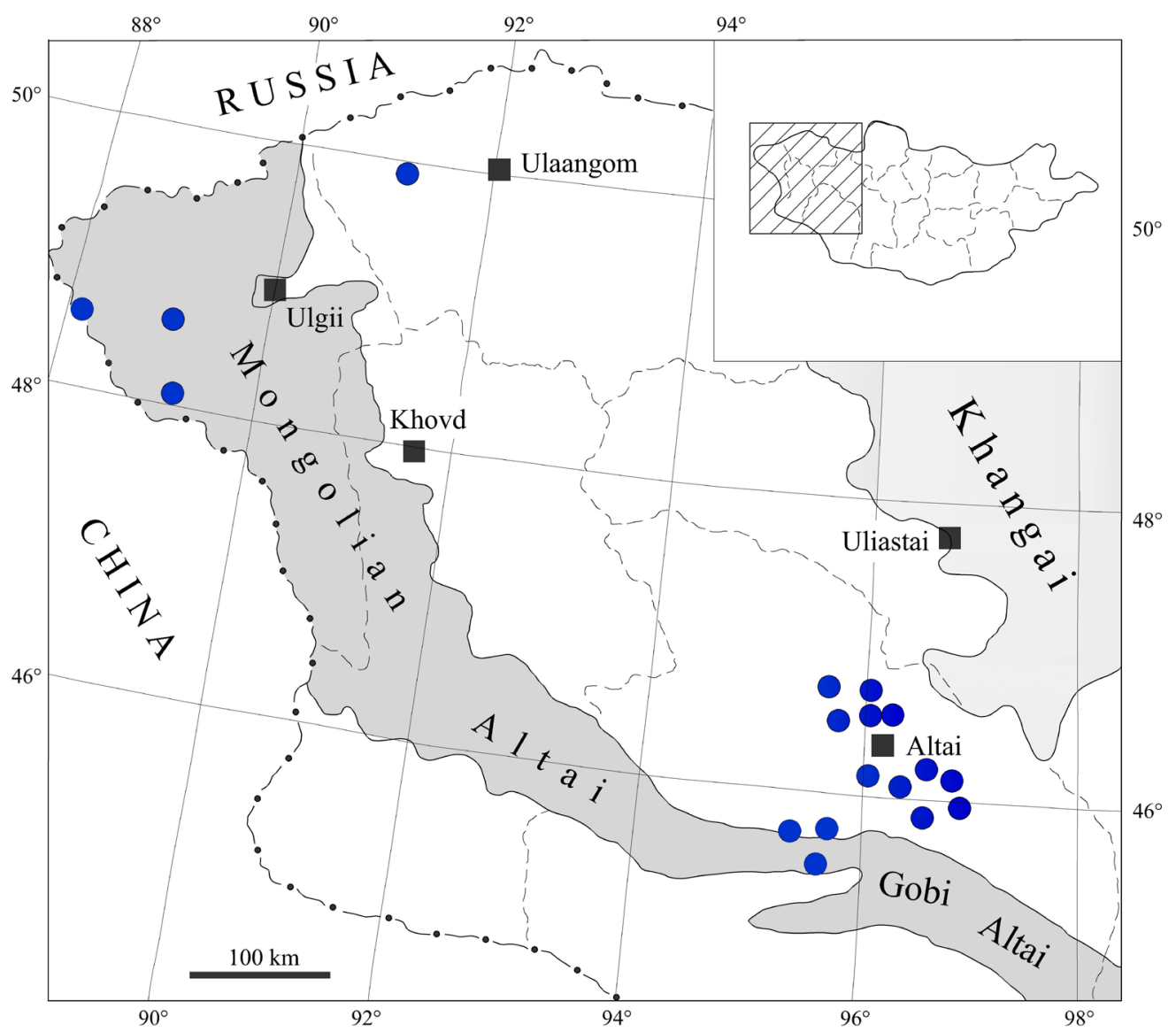

\section{Legend:}

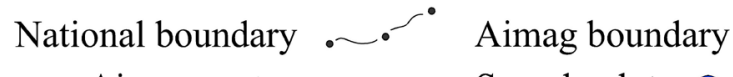

\section{Aimag center $\square \quad$ Sample plot}

Figure 1. Location of sample plots in the Mongolian Altai 
At present, there are no studies on the tree growth intensity and productivity of natural Siberian larch stands in the Mongolian Altai, while other studies are basically aimed at studying climate change, animal impact on

\section{MATERIALS AND METHODS}

We established square shaped 19 sample plots (0.12 ha) in representative parts of the forests in the Mongolian Altai. In the sample plots, all trees were numbered, tree height, diameter at breast height of each individual was measured. A total of 19 tree samples were taken from trees with average values for the laboratory stem analyses. The tree growth intensity analyses were performed on the basis forest regeneration and biodiversity. In this study we aimed at 1) identify lower and upper bounds in altitude of Siberian larch forests in the Mongolian Altai, and, 2) analyse tree growth intensity in stands. of decadal diameter increment.

While in our field survey we marked the upper and lower limits of the forest distribution by measuring altitude with GPS in each site.

For the statistical analysis we used natural quantitative indices [3], [4]. This method rather well discerns the tree growth intensity difference between separated forests.

$$
q(x) / \bar{q}(x)=\mathrm{WH}_{\mathrm{\alpha}}^{\mathrm{n}} * \mathrm{X}+\mathrm{WH}_{\mathrm{o}}^{\mathrm{n}}
$$

Where: $\mathrm{H}$ is the tree height; $\mathrm{q}(\mathrm{x})$ is the growth function of the stand; $\mathrm{X}$ is the stand age; $\bar{q}$ is the general function of the height; $\alpha$

\section{RESULTS AND DISCUSSION}

Distribution, and lower and upper altitude limits of Siberian larch forests

In the Mongolian Altai, there are two types of forests such as goltsy and pseudo-taiga larch forests, which mainly grow on the northern slopes of the mountains, and grow as a grove of trees (Fig. 2).

In the context of forest species composition Siberian larch (Larix sibirica Ledeb.) was a dominant species, and the stands mainly consist of two layers. 200 to 280 year old overmatured larch trees mainly create an upper layer in the forests.

Upper and lower limits of larch forest distribution were different in these four sites. We found that larch forests of Khasagt Khairkhan and Khan Taishir mountains (2300$2700 \mathrm{~m}$ a.s.l.) belong to Goltsy (Tsaram) is the angular value; $\mathrm{W}$ is the growth value; $\mathrm{n}$ is the natural number; $o$ is the zero value.

forests, and pseudo-taiga forests were found in the Khar Azarga (2100-2300 m) and around the Dayan and Khoton lake mountains.

In the Khar Azarga mountains we found that the pseudo-taiga forests were distributed at an altitude of 2100-2300 m, goltsy forests at $2300-2600 \mathrm{~m}$, and in around the Dayan and Khoton lake watersheds, the pseudotaiga forests were distributed at an altitude of 2200-2300 m a.s.1, and goltsy forests at 2300$2500 \mathrm{~m}$ a.s.1 respectively. Consequently, we discovered that the upper limit of the larch forest distribution reached as high as $2700 \mathrm{~m}$ a.s.l in the Mongolian Altai. Therefore, in the context of slope distribution, more than 52 percent of the forested area grow at a gradient of 25 to 34 degrees. 


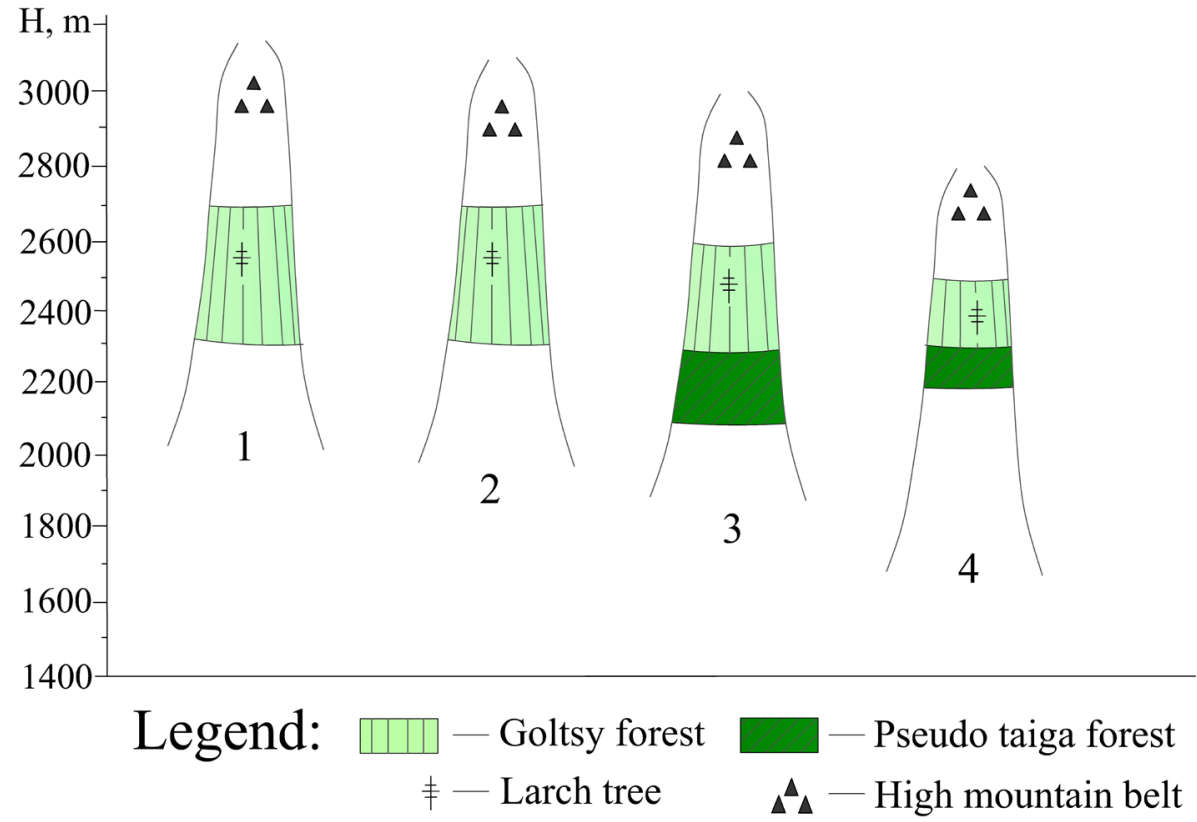

Figure 2. Altitudinal belts of larch forests in the Mongolian Altai

1 - Khasagt Khairkhan mountain, 2 - Khantaishir mountain, 3 - Khar Azarga mountain, 4 - around Dayan and Khoton lakes

\section{Forest age structure}

Results of the investigation indicate that there is an unequal age-class distribution of larch forests in the Mongolian Altai. In forest age structure, most of forested areas belong to middle (32 percent) and over mature (58

percent) classes and less than 10 percent belong to mature forests (Fig. 3). Absence of young stands proves that there is a very poor natural regeneration in the Mongolian Altai range.

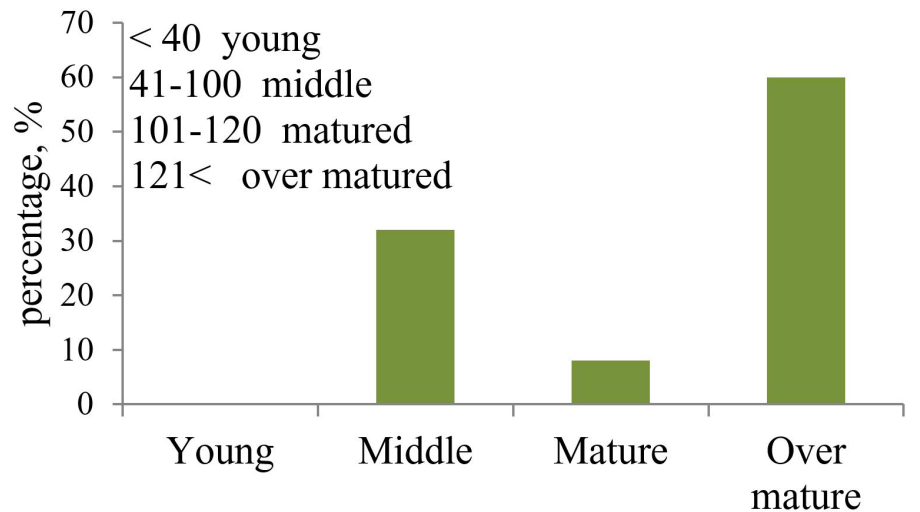

Figure 3. Forests by age classification 


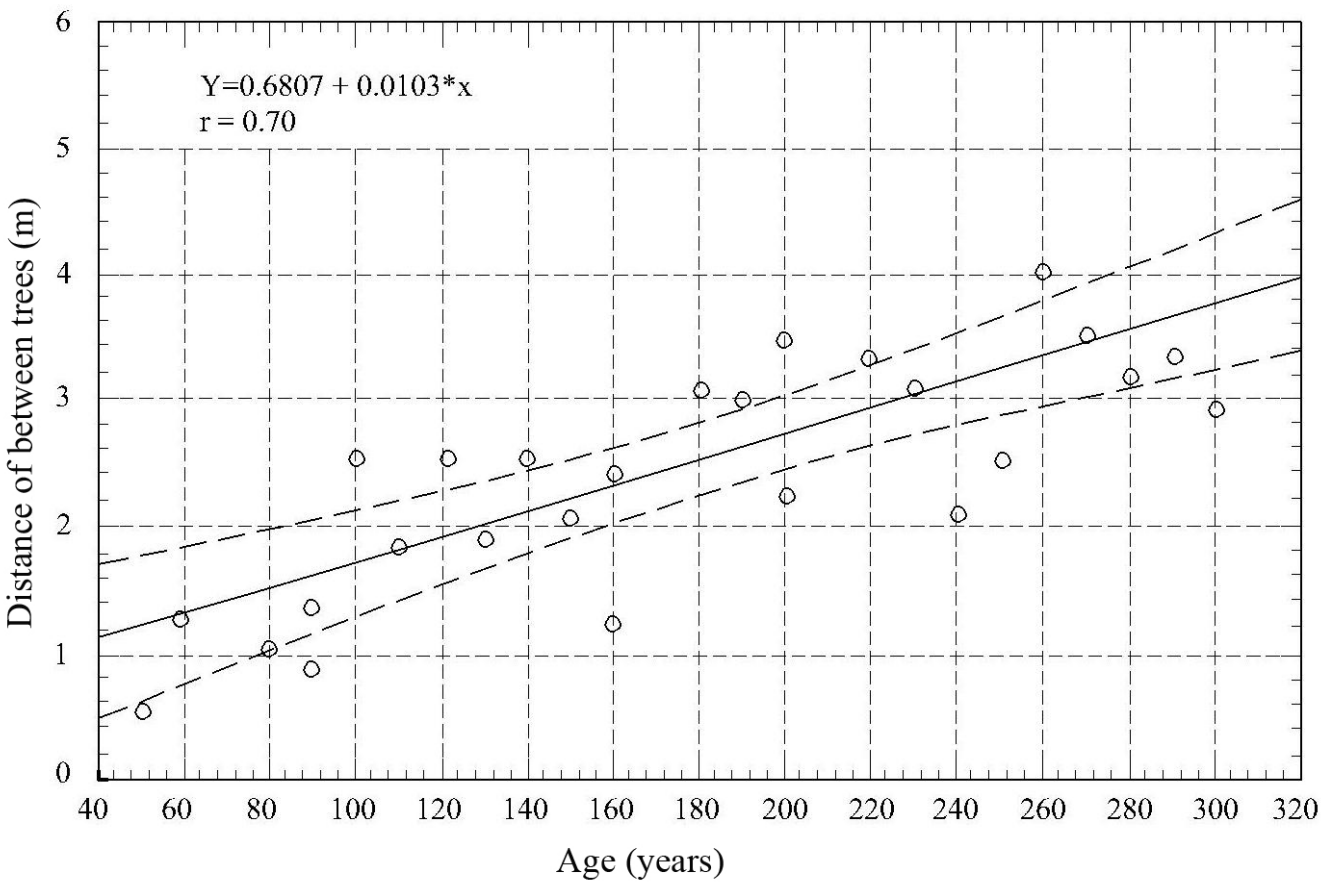

Figure 4. Relationship between tree spacing and stand age

Tree density in middle-aged stands often higher than mature and over-mature stands, which is caused by the relationship between stand density and age $(\mathrm{r}=0.7)$. If the first stage of the forest formation stand density is always relatively higher, then self-thinning reduces the stand density with forest ages $(r=0.7$, $\mathrm{p}<0.05$ ) (Fig. 4).

\section{Diameter growth rate of larch forests}

Tree growth intensity is absolutely different in each tree. When the growth rate is fast, growth rates of young tree will be relatively intense and the growth rate will slow down as the age progresses. Zero value of the growth rate as $\left(\mathrm{WH}_{\mathrm{o}}^{\mathrm{n}}\right)$ emphasized in the method of natural quantitative index. Zero value $\left(\mathrm{WH}_{\mathrm{o}}^{\mathrm{n}}\right)$ is calculated by mathematical statistical method of the least squares. The value of quantitative data means that the growth of the stand is very intense at a young age.

Our findings demonstrated that natural quantitative indices $\left(\mathrm{WH}_{\mathrm{o}}^{\mathrm{n}}\right)$ for model trees were different and ranged from 0.393 to 1.879 (Table 1). These indices show that there is a significant difference in diameter growth rate between forests. Depending on natural quantatitive indices $\left(\mathrm{WH}_{\mathrm{o}}^{\mathrm{n}}\right)$, growth rate of all stands were divided into fast-growing $\left(\mathrm{WH}_{\mathrm{o}}^{\mathrm{n}}\right.$ $\geq 1.0$ ) and slow-growing $\mathrm{WH}_{\mathrm{o}}^{\mathrm{n}}<1.0$.

Table 1. Natural quantities of diameter growth larch trees

\begin{tabular}{|c|l|r|r|}
\hline № & Sample plot & WH $_{\alpha}{ }^{n}$ & WH ${ }^{n}$ \\
\hline 1 & DKH-1 & -0.003 & 1.105 \\
\hline 2 & DKH-2 & -0.001 & 0.967 \\
\hline 3 & DKH-3 & -0.005 & 1.528 \\
\hline 4 & DKH-4 & -0.001 & 0.971 \\
\hline
\end{tabular}




\begin{tabular}{|r|l|r|r|}
\hline 5 & KHKH -1 & -0.001 & 1.116 \\
\hline 6 & KHKH -2 & -0.004 & 1.424 \\
\hline 7 & KHKH -3 & -0.001 & 1.158 \\
\hline 8 & KHKH -4 & 0.007 & 0.480 \\
\hline 9 & KHT-1 & 0.004 & 0.612 \\
\hline 10 & KHT-2 & 0.004 & 0.527 \\
\hline 11 & KHT-3 & 0.003 & 0.696 \\
\hline 12 & KHT-4 & 0.005 & 0.393 \\
\hline 13 & KHA-1 & 0.003 & 0.753 \\
\hline 14 & KHA-2 & 0.005 & 0.553 \\
\hline 15 & KHA-3 & -0.004 & 1.503 \\
\hline 16 & CKH-1 & 0.005 & 0.584 \\
\hline 17 & CKH-2 & -0.004 & 1.482 \\
\hline 18 & CKH-3 & -0.001 & 1.180 \\
\hline 19 & CKH-4 & -0.010 & 1.879 \\
\hline
\end{tabular}

Notes: $\quad$ DKH - Dayan and Khoton lake, KHKH - Khasagt Khairkhan, KHT - Khan Taishir,

KHA - Khar Azarga, CKH - Central Khangai

In accordence with this criteria, we calculated the diameter growth rate for all model trees as illustrated in Table 2.

Table 2. Classification of diameter growth rate by percentage

\begin{tabular}{|c|l|l|}
\hline \multirow{2}{*}{$\begin{array}{c}\text { Forest }- \\
\text { vegetation zone }\end{array}$} & \multicolumn{2}{|c|}{ Growth rate } \\
\cline { 2 - 3 } Mongolian Altai & $\begin{array}{c}|c| \\
\text { DKH-1, DKH-3, KHKH-1, } \\
\text { KHKH -2, KHKH -3, KHA-3, }\end{array}$ & $\begin{array}{l}\text { Slow-growing } \\
\text { KHT-2, DKH -4, KHKH -4, KHT-1, } \\
\text { KHA-2 }\end{array}$ \\
\hline Central Khangai -3, KHT -4, KHA-1, & CKH-2, CKH -3, CKH -4 & CKH -1 \\
\hline \multicolumn{2}{|c|}{ Percentage, \% } \\
\hline Mongolian Altai & 40 & 60 \\
\hline Central Khangai & 75 & 25 \\
\hline
\end{tabular}

Results of the assessments showed that slow-growing larch stands, which occupy more than 60 percent of total larch forest distribution, and predominant in the Mongolian Altai. Such a small percentage of fast-growing stands in this region maybe the result of limited growing conditions, such as high altitude and aridity (Table 2).
Table 3 shows that for assessing the growth rates, relative diameter of $10,20,30 \ldots 100$ years old larch trees were calculated using this method. Table 4 shows the relationship between normal value of diameter growth of larch trees and average normal value. Table 5 shows the relationship between normal value of diameter growth of larch trees and tree age. 


\section{Discussion}

In Mongolia, there are 4 different types of altitude complex of forest distribution including sub-taiga, taiga, pseudo-taiga and sub-alpine [5]. Pseudo-taiga in Mongolia has a wide distribution involving the Khuvsgul, Darkhadyin Khotgor, areas around Khuvsugul lake at an altitude of 1,550-1,950 $\mathrm{m}$ [6], in Central Khangai at 1,300-1,800 m, in the Mongolian Altai at 2,100-2,300 m a.s.l. Therefore, sub-alpine forests are distributed in the Khuvsguol area at an altitude of 1,9002,300 $\mathrm{m}$, in the Central Khangai region at 1,300-2,600 $\mathrm{m}$, and in the Mongolian Altai at an altitude of 2,300-2,500 $\mathrm{m}$ a.s.1 [7].

Previous studies reported that in the Central Khangai region, pseudo-taiga larch forests are more productive than the larch forests in the Mongolian Altai, and cover more than 80 percent of the total forest distribution [8]. We first determined that the upper limit of the sub-alpine larch forests in the Mongolian

\section{CONCLUSIONS}

Larch forests in the Mongolian Altai have enormous ecological significance, and in the context of age class structure, the forests are basically dominated by over-matured stands. We found that the upper limit of Goltsy larch forests in the Mongolian Altai reached up to 2,700 $\mathrm{m}$ a.s.1. In general, the growth rate of trees in the Mongolian Altai is relatively slower and less productive than in other regions of the
Altai reached up to 2,700 $\mathrm{m}$ a.s.1. Species composition and altitude distribution of the forests in the Mongolian Altai are different from the forests in the Russian Altai mountain ranges. In Central Altai of Russia, theupper limit of forest distribution reaches an altitude of 2,150 $\mathrm{m}$ a.s.1. [9].

V. V. Zagreev classified 16 types of growth rate in pine forests [10]. I. V. Mikhov suggested to use natural quantitative indices for determination of tree growth rate, and growth rate may be divided into normal-growing, slow-growing and fast-growing [4], [11]. In this study, taking account of forest distribution and growth performance of larch forests, we used only two categories of growth rate (fast and slow). We found the slowest growth rate of larch forests in Khan Taishir, and relatively lower rates in the forests near Dayan Khoton lake (50\%), and Khar Azarga mountain forests $(30 \%)$ respectively.

country.

The slowest growth rate of larch forests is observed on the Khan-Taishir mountain, which is the southernmost tip of Mongolia's coniferous forests. The relatively slow growth rate of larch forests in the Mongolian Altai is a product of the sharp continental climate and aridity, as well as high altitude.

\section{REFERENCES}

[1] Korotkov. I. A., Tsedendash, G., Forest map of Mongolia, Scale 1:1.5 mln. GUGK USSR and MPR, M, 1983, In Mongolian.

[2] Dulamsuren, C., Khishigjargal, M., Leuschner, C., Hauck, M., Response of tree-ring width to climate warming and selective logging in larch forests of the Mongolian Altai, J Plant Ecol, doi:10.1093/jpe/rtt019, 2013a.

[3] Dukhovnikov, Yu., Mikhov, I. V., Mountain forest taxation.Sofia, 1983. In Bulgarian.

[4] Mikhov, I. V., Method for determining the type of growth and its application in differentiated site index of natural pinestands, Doctoral dissertation, 1986, In Bulgarian.

[5] Korotkov, I. A., Dugarjav, Ch., Patterns of forest distribution in the MPR/ Proceedings of the Institute of Botany, Academy of Sciences of Mongolia, No1, pp. 162-185, 1976, In Mongolian. 
[6] Tsedendash, G., Forests and lake of Khuvsgul. Natural resources and the situation around Khuvsgul, Ulaanbaatar, p. 73-76, 1995, In Mongolian.

[7] Dugarjav, Ch., Larch forests in Mongolia, Bembisan press, Ulaanbaatar, p. 318, 2006, In Mongolian.

[8] Forests of the MPR,. Larch forest of Central Khangai, Nauka, M., p. 147, 1983, In Russian.

[9] Panyushkina, I. P., Ovchinnikov, D. V., 1999, Larch trees annual diameter increment response to climate in Altai mountain of Russia//Forestry, M, No 6, pp. 22-32, In Russian.

[10] Zagreev, V. V., Typification and standardization of natural rows growth of stands, Journal of Forestry, No 11, 1976, In Russian.

[11] Mikhov, I. V., Differentiated site index curves for white pine stand, Scientific, Tr., VLTI. T. XXVII, 1983, In Bulgarian. 


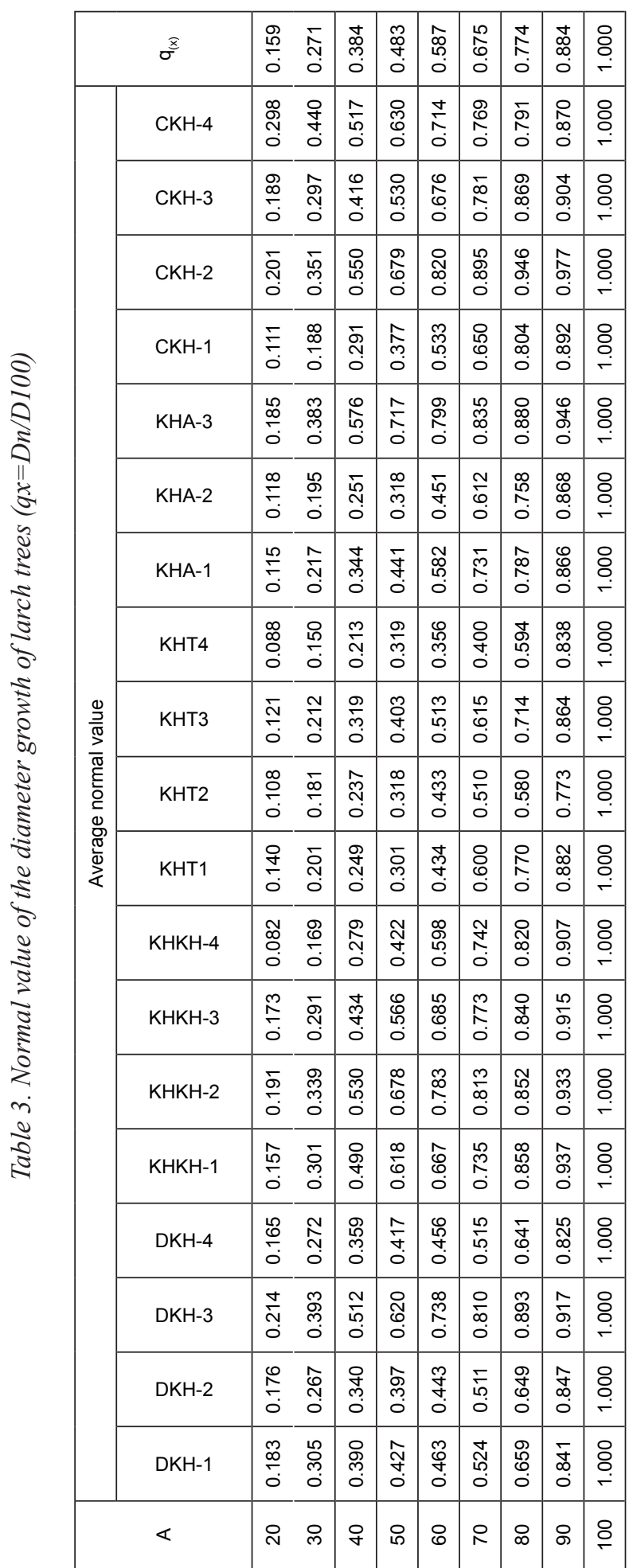

4

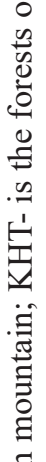

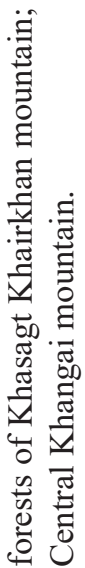

$\begin{array}{ll}0 & 4 \\ \pm & 0 \\ .0 & 0 \\ 1 & 0 \\ 1 & 0\end{array}$

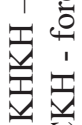

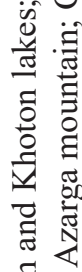

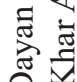

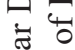

离

인

$\underset{\Xi}{ \pm}$

离

$\pm$

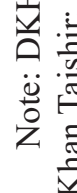




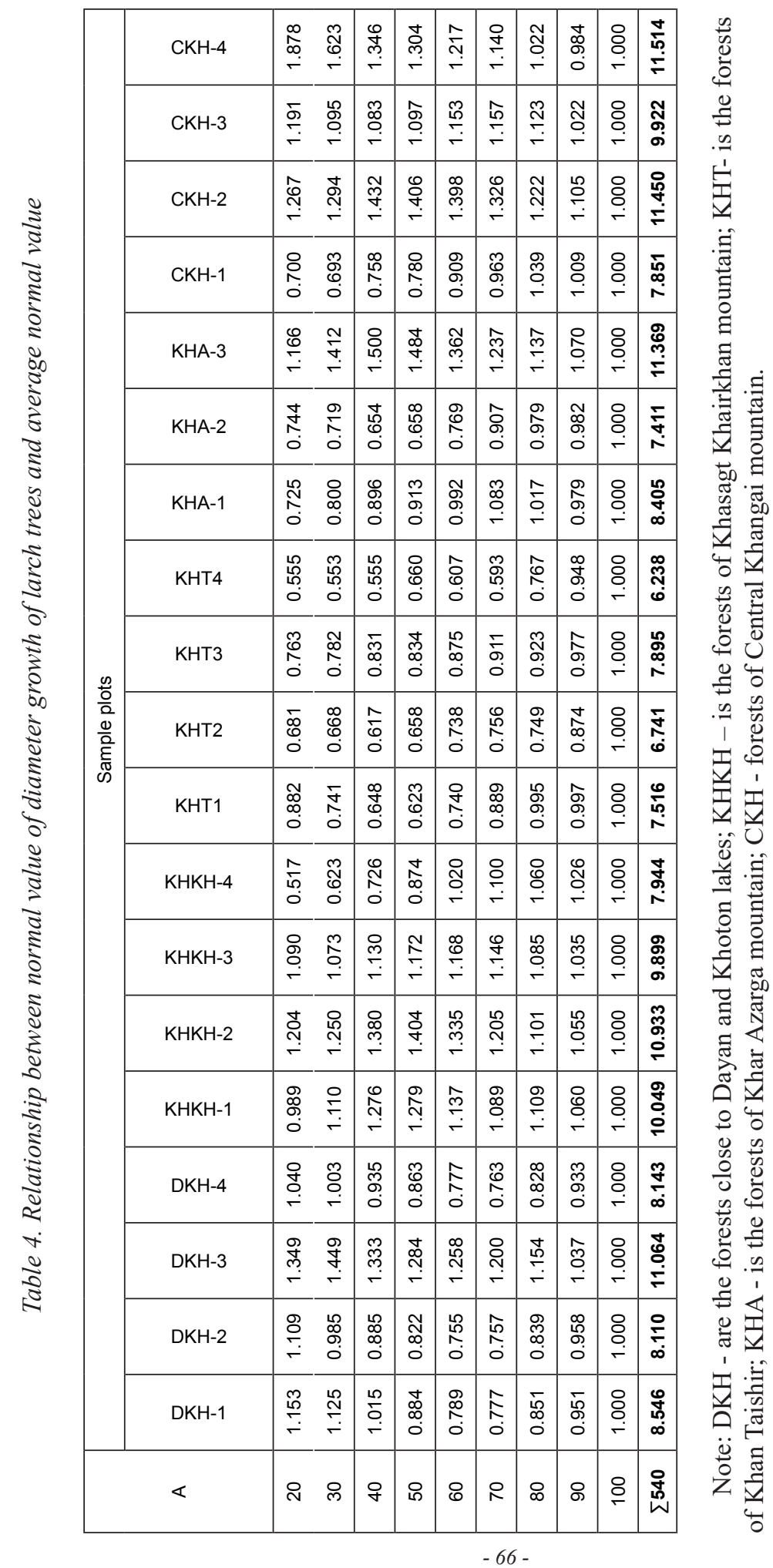




\begin{tabular}{|c|c|c|c|c|c|c|c|c|c|c|c|c|}
\hline \multicolumn{2}{|r|}{ 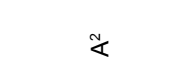 } & & ৪ & $\stackrel{\circ}{\circ}$ & 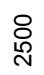 & $\begin{array}{l}\stackrel{8}{0} \\
\text { }\end{array}$ & ঃ্ণি & $\begin{array}{l}8 \\
\stackrel{+}{0} \\
\end{array}$ & $\frac{8}{\infty}$ & ষ̊ & 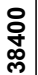 & $\frac{n}{\tilde{y}}$ \\
\hline \multirow{19}{*}{ 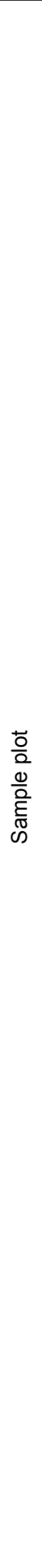 } & CKH-4 & 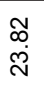 & 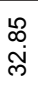 & 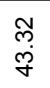 & 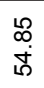 & $\frac{\infty}{8}$ & 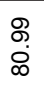 & $\begin{array}{l}+ \\
\infty \\
\infty \\
\infty \\
\infty\end{array}$ & $\frac{\stackrel{\circ}{\circ}}{\bar{\sigma}}$ & $\begin{array}{l}\text { ¿ } \\
\text { ¿ }\end{array}$ & $\begin{array}{l}\mathscr{m} \\
0 \\
0 \\
0 \\
0 \\
i\end{array}$ & $\stackrel{\Xi}{ \pm}$ \\
\hline & $\mathrm{CKH}-3$ & 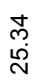 & $\begin{array}{l}\underset{\infty}{\infty} \\
\stackrel{\infty}{\infty}\end{array}$ & 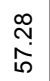 & $\begin{array}{l}\stackrel{\rho}{0} \\
\text { í }\end{array}$ & $\begin{array}{l}\infty \\
\infty \\
\infty \\
\infty\end{array}$ & 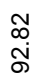 & $\begin{array}{l}\stackrel{2}{2} \\
\hat{\sigma}\end{array}$ & $\begin{array}{l}\text { டி } \\
\text { ه̊ }\end{array}$ & $\begin{array}{l}\text { ¿ } \\
\text { ¿ }\end{array}$ & 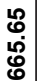 & \\
\hline & CKH-2 & $\begin{array}{l}\stackrel{8}{0} \\
+ \\
+\end{array}$ & $\begin{array}{l}\stackrel{2}{2} \\
\text { î }\end{array}$ & 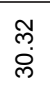 & ষ্. & $\begin{array}{l}\text { Lे } \\
\dot{0} \\
\dot{0}\end{array}$ & 宅 & $\underset{\infty}{\stackrel{\infty}{\infty}}$ & $\begin{array}{l}\bar{\infty} \\
\stackrel{8}{ }\end{array}$ & $\begin{array}{l}\text { ㅇ } \\
\text { ष्ठ }\end{array}$ & 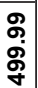 & \\
\hline & CKH-1 & ্ָ心 & 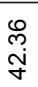 & $\begin{array}{l}8 \\
8 \\
8\end{array}$ & 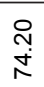 & $\frac{\mathbb{N}}{\stackrel{\infty}{-}}$ & 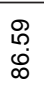 & $\begin{array}{l}8 \\
\stackrel{8}{8}\end{array}$ & $\begin{array}{l}\stackrel{ल}{~} \\
\ddot{\leftrightarrow}\end{array}$ & $\begin{array}{l}\text { ㅇ. } \\
\text { षे }\end{array}$ & 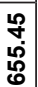 & \\
\hline & KHA-3 & 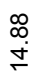 & 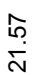 & $\frac{0}{\dot{\sigma}}$ & ণ্লি & $\underset{\substack{\sigma \\
\dot{g}}}{ }$ & 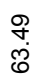 & $\begin{array}{l}\widetilde{0} \\
\substack{\infty \\
\infty}\end{array}$ & $\begin{array}{l}\infty \\
\infty \\
\infty \\
\infty \\
\infty\end{array}$ & $\begin{array}{l}\text { ㅇ. } \\
\text { ه }\end{array}$ & 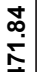 & \\
\hline & KHA-2 & $\begin{array}{l}\stackrel{\circ}{\circ} \\
\stackrel{+}{\leftarrow}\end{array}$ & $\begin{array}{l}\stackrel{8}{\dot{d}} \\
\dot{\mathrm{N}}\end{array}$ & 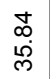 & $\begin{array}{l}\text { ஜ } \\
\dot{b}\end{array}$ & $\begin{array}{l}\text { त్ } \\
\text { هి }\end{array}$ & $\begin{array}{l}\bar{\infty} \\
\stackrel{\rho}{\rho}\end{array}$ & $\begin{array}{l}\infty \\
\stackrel{\infty}{\infty}\end{array}$ & $\underset{\infty}{\underset{\infty}{\infty}}$ & $\begin{array}{l}\text { ㅇ. } \\
\text { ¿ }\end{array}$ & 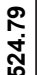 & \\
\hline & $\mathrm{KHA}-1$ & 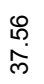 & $\begin{array}{l}\stackrel{8}{6} \\
\stackrel{\infty}{+}\end{array}$ & \begin{tabular}{l}
\multirow{\infty}{0}{} \\
ஸే
\end{tabular} & 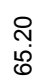 & $\begin{array}{l}\tilde{O} \\
\text { న } \\
\end{array}$ & 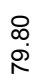 & $\begin{array}{l}\stackrel{0}{2} \\
\stackrel{\infty}{-}\end{array}$ & $\begin{array}{l}0 \\
\infty \\
\infty \\
\infty\end{array}$ & $\begin{array}{l}\text { \& } \\
\text { ठ․ }\end{array}$ & 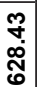 & 5 \\
\hline & KHT4 & $\stackrel{ }{\stackrel{ }{F}}$ & $\begin{array}{l}\stackrel{8}{0} \\
\stackrel{0}{\circ}\end{array}$ & 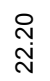 & 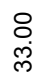 & $\begin{array}{l}\text { ণे } \\
\grave{ల}\end{array}$ & $\frac{\bar{\zeta}}{\frac{i}{\sigma}}$ & $\begin{array}{l}\stackrel{e}{m} \\
\dot{\sigma}\end{array}$ & $\begin{array}{l}\widetilde{m} \\
\stackrel{\infty}{\infty}\end{array}$ & $\begin{array}{l}\text { ¿ } \\
\text { ष्் }\end{array}$ & 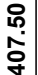 & \\
\hline & KHT3 & $\begin{array}{l}\stackrel{0}{N} \\
\stackrel{\omega}{\sim}\end{array}$ & $\begin{array}{l}\mathscr{0} \\
\stackrel{్}{N}\end{array}$ & 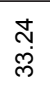 & $\begin{array}{l}\stackrel{R}{+} \\
\dot{\tau}\end{array}$ & $\begin{array}{l}\text { م્ } \\
\text { ஸి }\end{array}$ & $\begin{array}{l}\hat{\jmath} \\
\tilde{\theta}\end{array}$ & 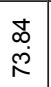 & $\underset{\infty}{\stackrel{\infty}{\infty}}$ & $\begin{array}{l}\text { ¿ } \\
\text { ¿ }\end{array}$ & 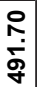 & \\
\hline & KHT2 & $\begin{array}{l}\widetilde{\sigma} \\
\stackrel{\rho}{\sim}\end{array}$ & $\begin{array}{l}\text { ¿े } \\
\text { iे }\end{array}$ & $\begin{array}{l}\infty \\
\stackrel{\sim}{\sim} \\
\end{array}$ & 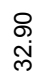 & \begin{tabular}{l}
$\stackrel{\infty}{N}$ \\
\multirow{J}{*}{}
\end{tabular} & ๙ુ & $\begin{array}{l}\tilde{\sigma} \\
\stackrel{0}{0}\end{array}$ & $\begin{array}{l}\otimes \\
\infty \\
\infty\end{array}$ & $\begin{array}{l}\text { ¿. } \\
\text { ¿ }\end{array}$ & $\begin{array}{l}\mathfrak{N} \\
\dot{\tilde{N}}\end{array}$ & \\
\hline & KHT1 & $\begin{array}{l}\stackrel{J}{\circ} \\
\stackrel{2}{\digamma}\end{array}$ & $\underset{\underset{N}{N}}{\stackrel{N}{N}}$ & $\begin{array}{l}\tilde{\leftrightarrow} \\
\stackrel{\sim}{\omega}\end{array}$ & $\stackrel{n}{\stackrel{m}{m}}$ & $\begin{array}{l}\stackrel{+}{+} \\
\dot{y}\end{array}$ & 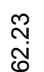 & $\begin{array}{l}\circ \\
\text { o }\end{array}$ & 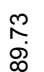 & $\begin{array}{l}\text { ㅇ. } \\
\text { ه }\end{array}$ & 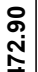 & \\
\hline & KHKH-4 & 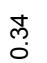 & $\stackrel{8}{\infty}$ & $\begin{array}{l}\dot{0} \\
\dot{\sigma}\end{array}$ & $\stackrel{R}{i}$ & 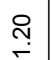 & $\stackrel{8}{1}$ & 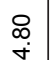 & 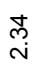 & ஃ. & $\stackrel{F}{\Sigma}$ & \\
\hline & KHKH-3 & $\frac{\infty}{\stackrel{\infty}{N}}$ & $\frac{\mathscr{\sigma}}{\underset{N}{N}}$ & $\begin{array}{l}\text { กิ } \\
\text { if }\end{array}$ & $\begin{array}{l}\stackrel{8}{0} \\
\stackrel{\infty}{\circ} \\
\infty\end{array}$ & \begin{tabular}{l}
$\infty$ \\
$\stackrel{0}{\circ}$ \\
\hdashline
\end{tabular} & $\begin{array}{l}\underset{\infty}{N} \\
\stackrel{\infty}{\infty}\end{array}$ & $\begin{array}{l}\infty \\
0 \\
\infty\end{array}$ & $\frac{\llcorner}{\frac{\infty}{\not ்}}$ & $\begin{array}{l}8 \\
8 \\
8\end{array}$ & 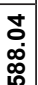 & \\
\hline & KHKH-2 & $\begin{array}{l}\stackrel{\infty}{\circ} \\
\dot{\sim}\end{array}$ & 菖 & $\begin{array}{l}\text { 尺ิ } \\
\text { Ln }\end{array}$ & సָָ & $\frac{\circ}{\stackrel{0}{0}}$ & $\begin{array}{l}\stackrel{\infty}{\infty} \\
\dot{\infty}\end{array}$ & $\begin{array}{l}\infty \\
\infty \\
\infty\end{array}$ & $\begin{array}{l}\mathscr{\wp} \\
\dot{\sigma}\end{array}$ & $\begin{array}{l}\text { ¿. } \\
\dot{8}\end{array}$ & $\begin{array}{l}0 \\
+ \\
\dot{p} \\
\end{array}$ & \\
\hline & KHKH-1 & $\begin{array}{l}\stackrel{\infty}{\sim} \\
\stackrel{\circ}{\leftarrow}\end{array}$ & 户্লি & $\frac{\dot{d}}{\dot{x}}$ & $\begin{array}{l}\text { مू } \\
\text { లే }\end{array}$ & $\begin{array}{l}\mathbb{N} \\
\underset{\infty}{0} \\
0\end{array}$ & 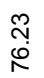 & $\begin{array}{l}\mathbb{N} \\
\infty \\
\infty\end{array}$ & $\begin{array}{l}\text { ơ } \\
\text { ஜूं }\end{array}$ & $\begin{array}{l}8 \\
8 \\
8\end{array}$ & $\begin{array}{l}\mathbf{d} \\
\dot{0} \\
0 \\
0\end{array}$ & \\
\hline & DKH-4 & $\begin{array}{l}\infty \\
\infty \\
\stackrel{N}{N}\end{array}$ & $\begin{array}{l}\text { 8. } \\
\text { வें }\end{array}$ & $\begin{array}{l}\text { g̣ } \\
\text { હे }\end{array}$ & $\stackrel{\stackrel{L}{~}}{\stackrel{p}{q}}$ & $\begin{array}{l}\tilde{\emptyset} \\
\dot{\sigma}\end{array}$ & 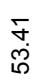 & 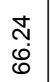 & $\begin{array}{l}\hat{\infty} \\
\infty \\
\infty\end{array}$ & $\begin{array}{l}\text { ¿ } \\
\text { ¿े }\end{array}$ & $\begin{array}{l}\infty \\
\stackrel{\infty}{0} \\
\stackrel{5}{\infty}\end{array}$ & \\
\hline & DKH-3 & $\begin{array}{l}\infty \\
\stackrel{\infty}{0} \\
\stackrel{\leftrightarrow}{\sim}\end{array}$ & $\underset{\stackrel{5}{\sigma}}{\stackrel{\gamma}{\sigma}}$ & $\begin{array}{l}\widetilde{m} \\
\tilde{ల}\end{array}$ & $\begin{array}{l}\text { N } \\
\text { ¿े }\end{array}$ & 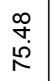 & $\begin{array}{l}8 \\
\text { வे } \\
\dot{\infty}\end{array}$ & $\begin{array}{l}\text { ల్ } \\
\text { } \\
\text { J }\end{array}$ & $\begin{array}{l}\stackrel{m}{\infty} \\
\stackrel{\leftrightarrow}{\circ}\end{array}$ & $\begin{array}{l}\text { ¿ } \\
\text { ¿ }\end{array}$ & 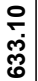 & \\
\hline & DKH-2 & $\frac{\infty}{\stackrel{N}{N}}$ & 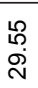 & $\begin{array}{l}\text { q } \\
\text { b }\end{array}$ & $\frac{\text { 움 }}{\dot{\sigma}}$ & $\begin{array}{l}\text { Oे } \\
\text { bீ }\end{array}$ & 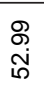 & 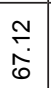 & $\begin{array}{l}\text { N } \\
\stackrel{0}{ }\end{array}$ & $\begin{array}{l}\text { ㅇ․ } \\
\text { ष्் }\end{array}$ & 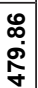 & \\
\hline & DKH-1 & $\begin{array}{l}\mathscr{O} \\
\stackrel{\aleph}{N}\end{array}$ & 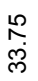 & $\begin{array}{l}\stackrel{0}{0} \\
\dot{q}\end{array}$ & 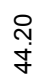 & $\underset{\stackrel{N}{\sim}}{\stackrel{+}{f}}$ & $\begin{array}{l}\text { m } \\
\text { ¿े }\end{array}$ & $\begin{array}{l}\infty \\
0 \\
\infty \\
0\end{array}$ & $\begin{array}{l}\stackrel{8}{\circ} \\
\stackrel{\infty}{\infty} \\
\infty\end{array}$ & $\begin{array}{l}\text { \& } \\
\text { ष् }\end{array}$ & $\begin{array}{l}\bar{\vdots} \\
\dot{\sigma} \\
\dot{g}\end{array}$ & \\
\hline & $\ll$ & กิ & 户 & q & 요 & 8 & ? & $\infty$ & 8 & 음 & $w$ & \\
\hline
\end{tabular}

